\title{
DINAMIKA RUANG PKL ALUN-ALUN PONOROGO : SEBUAH KEARIFAN LOKAL
}

\author{
Achmad Faried Hanafi ${ }^{1}$, Lisa Dwi Wulandari ${ }^{2}$, Antariksa $^{3}$ \\ 1,2,3, Magister Arsitektur Lingkungan Binaan, Universitas Brawijaya \\ fariedhanafi@yahoo.com
}

\begin{abstract}
ABSTRAK
Sekarang ini sebagian besar alun-alun berubah menjadi taman kota yang berfungsi sebagai ruang terbuka publik pendukung fungsi sosial, estetika dan ekologis. PKL sebagai entitas ekonomi, tidak melepaskan kesempatan kerumunan massa pada ruang publik sebagai suatu potensi untuk kepentingan usahanya. Keberadaan PKL di alun-alun sebagai suatu simalakama, diperbolehkan atau dilarang. Penulisan ini bertujuan untuk memaparkan dinamika ruang PKL di alun-alun Ponorogo dan menggali keberadaannya sebagai suatu yang mengandung kearifan lokal. Pendekatan penulisan dengan metode deskriptif kualitatif yang berbasis pada indepth interview keyperson. Keberadaan PKL di alun-alun Ponorogo membentuk suatu dinamika ruang tersendiri dan sebagai wujud kearifan lokal yang berkembang di alun-alun Ponorogo.
\end{abstract}

Kata Kunci : alun-alun, Ponorogo, PKL, kearifan lokal.

\begin{abstract}
Nowadays most of alun-alun turned into an urban park that serves as public open space advocates social, aesthetic and ecological functions. PKL as an economic entity, do not lose on the chance of crowd people on public space as a potential market for their business. The existence of street vendors in the square had become a dilemma, allowed or prohibited. This research aims to describe the spatial dynamics of street vendors in alun-alun Ponorogo and explore its existence to study its local wisdom. This study used qualitative descriptive method based on indepth interview on keypersons. The existence of street vendors in alun-alun Ponorogo form spatial-dynamic and as a form of local wisdom that develops in alun-alun Ponorogo.
\end{abstract}

Keywords : alun-alun, Ponorogo, PKL (street vendors), local wisdom.

\section{Pendahuluan}

Alun-alun dan kawasan di sekitarnya bagi sebagian besar kota di Jawa identik dengan pusat kota. Hal tersebut dapat diamati dari beberapa aspek, yaitu posisi alunalun berada di tengah kota dengan disekitar alun-alun biasanya terdapat pusat pemerintahan dan fasilitas pelayanan masyarakat seperti tempat ibadah dan pasar. Selain itu kawasan di sekitar alun-alun merupakan kawasan yang mempunyai fungsi dan intensitas penggunaan lahan yang tinggi bila dibandingkan dengan kawasan lainnya. Kehadiran alun-alun sudah ada sejak jaman prakolonial. Meskipun dari dulu sampai sekarang bentuk fisik alun-alunnya sendiri tidak banyak mengalami perubahan, tapi konsep yang mendasari bentuk phisiknya sejak jaman prakolonial sampai sekarang telah mengalami banyak perubahan. Konsep inilah yang sebetulnya menentukan fungsi dan kehadiran alun-alun dalam suatu kota di Jawa [Wiryomartono,1995]. 
Sesudah kemerdekaan Indonesia nasib alun-alun kota bertambah parah lagi. Banyak pengambil keputusan atau kebijakan pembangunan kota ragu-ragu atau bahkan tidak mengerti mau difungsikan untuk apa alun-alun ini. Banyak alun-alun yang sekarang digunakan untuk tempat olah raga sepak bola, tenis, basket, ada pula yang sekarang difungsikan sebagai taman kota. Bahkan banyak yang sekarang tidak jelas fungsinya, karena pusat kotanya sudah bergeser ke lain lokasi. Kondisi kini secara umum alun-alun kota diincar investor untuk dibeli karena letaknya yang strategis di pusat kota. Semuanya ini sebagai akibat belum adanya suatu konsensus budaya yang jelas secara nasional, untuk bisa dipakai sebagai pegangan dalam menangani alun-alun yang ada sekarang, sehingga wajar kalau timbul kebingungan dalam menangani pembangunan nya. Jadi seperti apa yang dilihat sekarang pada alun-alun kota, ingin meninggalkan pola tradisional, tapi belum menemukan struktur-struktur baru yang mantap. Sekarang ini alun-alun kelihatan seperti 'hidup segan matipun enggan' [Handinoto,1992]. Untuk itu penelitian tentang alun-alun perlu terus dilakukan dan dikembangkan guna melestarikan konsep dan makna asli dari alun-alun.

Ponorogo sebagai salah satu kota di Jawa Timur dikenal mempunyai tradisi kebudayaan yang termasyhur, yaitu tradisi kesenian reognya. Kesenian ini mengakar kuat dan bertumbuh subur dimasyarakat Ponorogo. Pada waktu tertentu kesenian reog ditampilkan secara besar-besar di alun-alun Ponorogo. Selain pertunjukan reog, alunalun Ponorogo menjadi fokus perhelatan acara budaya yang dilaksanakan dalam rangka menyambut bulan muharam atau yang lebih sering kita dengar dengan istilah Grebeg Suro. Hal ini mengingatkan kita akan alun-alun Yogyakarta yang juga digunakan sebagai tempat pelaksanaan acara-acara budaya [Santoso,2008]. Keberadaan PKL di alun-alun menambah kemeriahan acara tersebut meskipun sehari-hari di alun-alun juga terdapat aktifitas PKL dengan jumlah dan skala yang lebih sedikit dan kecil.

Selain digunakan sebagai acara/kegiatan budaya, alun-alun Ponorogo juga dijadikan tempat untuk aktifitas kegiatan yang bersifat sosial, ekonomi, keagamaan bahkan politik karena alun-alun Ponorogo sekarang ini telah menjadi ruang publik bagi masyarakat Ponorogo. Berbagai jenis ragam aktifitas yang ada di alun-alun Ponorogo membentuk dinamika ruang aktifitas yang berbeda-beda disatu tempat bahkan kadang kala terjadi pada waktu yang bersamaan sehingga kemungkinan terjadi konflik ruang tinggi. Salah satu pengguna alun-alun adalah PKL yang juga merupakan sebagai pengguna tetap alun-alun Ponorogo. Keberadaan PKL di alun-alun turut serta dalam membentuk suatu dinamika ruang di alun-alun. Keberadaannya di alun-alun Ponorogo menjadi suatu pembeda dimana keberadaan PKL di sebagian alun-alun kota lainnya di Jawa Timur justru dilarang.

\section{Metode}

Penulisan ini bertujuan untuk memaparkan dinamika ruang PKL alun-alun Ponorogo dengan kearifan lokalnya. Pendekatan penulisan dengan metode deskriptif kualitatif yang berbasis pada indepth interview keyperson. Diharapkan dengan penggunaan metode ini dapat membantu mencapai tujuan yang diharapkan. Wawancara mendalam dilakukan terhadap keyperson PKL Alun-alun Ponorogo, pengunjung dan pemerintah sebagai penentu kebijakan, pemegang kontrol dan agen utama. 


\section{Hasil dan Pembahasan}

\subsection{Alun-alun Ponorogo dan PKL}

Alun-alun Ponorogo sebagai salah satu kearifan lokal lingkungan binaan yang telah ada sejak dulu. Keberadaan Fisik alun-alun tidaklah statis/tetap. Dari waktu kewaktu mengalami perubahan dan perkembangan. Perubahan dan perkembangan alun-alun ini secara fisik banyak ditentukan oleh pihak yang berkuasa (pemerintah). Hal ini dapat dimaklumi karena secara de yure dan de facto alun-alun memang sebuah wilayah yang masih dalam penguasaan pemerintah, baik dari kepemilikan maupun pengelolaan.

Alun-alun Ponorogo sebagaimana alun-alun pada kabupaten lainnya terdapat di depan pendopo kantor bupati dan sebelah barat terdapat masjid agung [Suwardjoko,2009]. Bentukan sebagai ruang terbuka dengan hamparan rumput dengan vegetasi beringin dan adanya paseban masih terlihat pada alun-alun Ponorogo, namun terdapat panggung utama yang luas, plasa patung singa di keempat pojok alun-alun dan perkerasan paving pada area tengah alun-alun. Hal ini yang menjadikannya dari segi fisik berbeda dengan alun-alun kabupaten lainnya.

Alun-alun Ponorogo yang berfungsi sebagai ruang publik digunakan untuk aktifitas-aktifitas sosial semisal berekreasi, bersantai, bersosialiasi, bercanda, bergurau, duduk, istirahat, bermain, dan berolahraga. Aktifitas-aktifitas budaya juga terjadi di alun-alun Ponorogo semisal pagelaran wayang kulit setiap malam minggu akhir bulan, pagelaran reog bulan purnama, pagelaran Festival Reog Mini (FRM), Festival Reog Nasional (FRN) dan pentas budaya lainnya.

Beberapa aktifitas sosial dan budaya menyebabkan orang untuk berkerumun di alun-alun sehingga kesan meruang alun-alun muncul karena kerumunan dan kerumunan di alun-alun itulah yang menjadikan daya tarik bagi orang untuk mendekat [Rukayah,2007]. Adanya kerumunan keramaian massa menjadi daya tarik bagi PKL untuk turut beraktifitas di alun-alun Ponorogo karena bagi PKL hal tersebut sebagai potensi untuk kepentingan usahanya. Ada kalanya keberadaan PKL sendiri menjadi penyebab orang untuk berkerumun di area tersebut. Alun-alun, sejak dahulu kala sampai sekarang, bagi sebagian anggota masyarakat adalah tempat mencari nafkah. PKL sudah ada sejak dahulu, perbedaannya dahulu lebih sebagai pedagang keliling sedangkan sekarang lebih banyak membangun jongko [Suwardjoko,2009].

Perubahan alun-alun secara drastis baik fisik maupun non-fisik dilakukan oleh Bupati Markum yang menjadi bupati dua periode, yaitu tahun 1994-1999 dan 19992004. Beberapa langkah beliau dimasa kepemimpinannya antara lain menetapkan hari jadi Kabupaten Ponorogo di isi dengan FRM, pentas reog di malam bulan purnama di sebelah utara paseban dan akhirnya dipentaskan di panggung utama yang dibangun pada tahun 2004. Penyelenggaraan kegiatan tersebut menjadi magnet yang luar biasa dalam menarik pengunjung untuk hadir dan melihat di alun-alun Ponorogo didukung dengan pembangunan fisik alun-alun Ponorogo yang mendukung acara-acara tersebut. Kesempatan keramaian massa ini dimanfaaatkan oleh PKL untuk membuka lapak-lapak usahanya. Jumlah PKL akan melonjak bila dibandingkan dengan jumlah PKL sehari-hari di alun-alun Ponorogo. Area aktifitas PKL yang membentuk ruang ekonomi ketika event tertentu akan berbeda dengan ruang ekonomi yang terbentuk oleh aktifitas PKL seharihari di alun-alun.

Kemudian pembenahan alun-alun terus dilakukan dimasa kepemimpinan bupati Amien tahun 2010-2015. Di antaranya: rehab paseban alun-alun, penambahan bangunan sayap samping kanan-kiri panggung utama dan penataan penghijauan alun- 
alun ponorogo. Pada massa kepemimpinan beliau PKL diberi tempat lebih leluasa dan berkembang di alun-alun.

\subsection{Dinamika ruang PKL sehari-hari}

Keadaan alun-alun saat pagi-siang hari minim dari aktifitas dikarenakan pada pagi-siang hari adalah jam kerja masuk kantor atau beraktifitas mencari nafkah. Namun ada beberapa aktifitas yang bisa dijumpai adalah kegiatan PKL rujak buah dan PKL minuman ringan (gambar 1). PKL ini sesuai dengan kondisi cuaca yang terik sehingga orang akan mencari minum untuk menghilangkan dahaga atau makan buah supaya segar. Keberadaan PKL rujak buah dan PKL minuman inilah yang rutin setiap hari. Namun keberadaan mereka biasanya mulai pukul 11.00 - 16.00. setelah itu mereka pulang atau melanjutkan berdagang keliling ditempat lain. Keberadaan PKL ini juga tidak serta merta sehari-hari bisa berjualan karena area PKL berjualan di jalan alun-alun utara yang merupakan akses utama keluar masuk kantor Bupati. Jika ada tamu dari luar ponorogo hendak ada kunjungan resmi, para PKL rujak buah dan PKL minuman diharap untuk tidak berjualan sementara karena mungkin bagi tamu yang akan datang keberadaan PKL dipandang kumuh dan kurang nyaman dilihat. Kearifan lokal yang ada menyebabkan hal ini tidak terjadi konflik. Para PKL menyadari bahwa pemerintah telah memberi kesempatan mereka mencari nafkah di jalan yang berdasarkan aturan umumnya dilarang berjualan di badan jalan dan mereka merasa juga ikut bertanggung jawab menjaga kehormatan pemerintah yang ketika itu ada tamu khusus. Pemerintah dalam memberi larangan juga tidak serta merta melarang dan mengusir mereka, namun biasanya mereka yang biasa berjualan di area tersebut dipanggil dan dikumpulkan untuk diberi pengarahan dan surat pemberitahuan agar tidak berjualan sementara karena alasan tertentu. Dengan adanya komunikasi yang selalu terbina dan berjalan harmonis maka konflik dapat seminim mungkin dihindari.

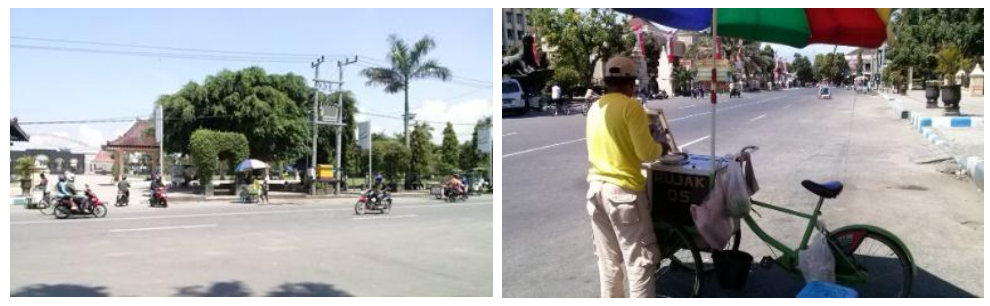

Gambar 1. PKL rujak buah di sebelah utara alun-alun (pagi-siang).

Disaat pengamatan penulisan, ditemui sebuah kearifan lokal. Para PKL rujak buah tidak pernah menyediakan buah yang siap kemasan untuk langsung dibawah pulang, melainkan pesanan dibuatkan langsung, dikupas buahnya didepan pembeli. Hal ini dilakukan dengan pertimbangan supaya pembeli tahu sendiri buah yang digunakan adalah buah yang masih segar dan bagus. Sisa dan kulit buah mereka masukan dalam tas sampah, hampir tidak ada yang tercecer. Ketika siang hari ada orang yang mengambil sampah-sampah kulit buah itu. Perkiraan awal penulis pengambil sampah itu adalah tukang sampah. Ternyata pengambil sampah itu adalah peternak unggas yang menggunakan kulit-kulit buah sebagai pakan unggas sehingga terjadi simbiolisme mutualisme yang baik, PKL tidak perlu susah payah membuang sampah dan peternak dapat makan ternak secara gratis. 

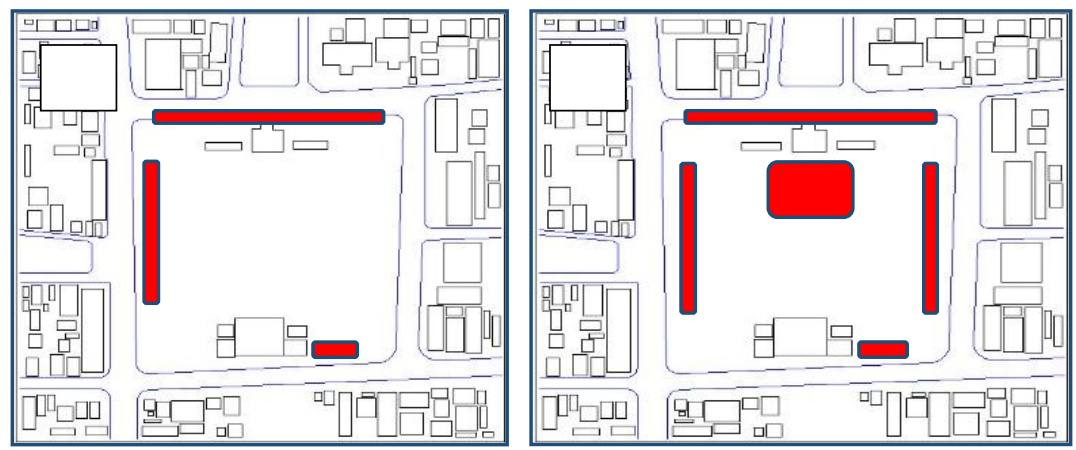

Gambar 2. Area penggunaan ruang alun-alun oleh PKL sehari-hari (pagi - siang) [A] dan (sore-malam) [B].

Aktifitas alun-alun mulai terlihat ketika jam 16.30. Dimana orang menuju kealunalun untuk bersantai disore hari dan para PKL bersiap-siap membuka stand PKL-nya. Namun aktifitas yang dilakukan masih memilih area yang tidak terlalu panas (area bayang-bayang, tidak terkena sinar matahari langsung). Hanya PKL yang telah membuka stand yang dikunjungi. Stand yang sering buka terlebih dahulu dibanding yang lain adalah stand wahana permainan. Para PKL tidak melewatkan kesempatan yang menjadikan alun-alun pada sore hari sebagai ruang sosial.

Setelah magrib para PKL sudah siap dengan semua dagangannya. Acuan waktu sholat (magrib) dipilih dengan alasan bahwa akan lebih menghormati jika beraktifitasnya PKL dilaksanakan setelah magrib. Jika melakukan aktifitas dagang ketika magrib bagi para PKL hal tersebut tidak bagus (gak ilok). Kalaupun dagangan sudah siap sebelum magrib, yang dilakukan adalah berhenti sejenak. Dari segi pengunjung bahwa waktu magrib adalah kurang tepat untuk beraktifitas diluar rumah. Menurut keyakinan orang jawa keluar magrib-magrib bikin celaka, pamali, nguwalati (gak ilok) karena diyakini waktu magrib adalah waktu setan-setan (mahluk halus) mulai keluar untuk beraktifitas.

Secara umum alun-alun sehari-hari ketika malam hari adalah ruang ekonomi yang terbentuk dari aktifitas bangkitan PKL (gambar 3). Terjadi dinamika ruang PKL dari semula pada pagi-siang hari hanya pada jalan depan pendopo dan sebagian barat alun-alun pada malam hari bertambah ruang PKL yang terbentuk pada area perkerasan paving utara (gambar 2).
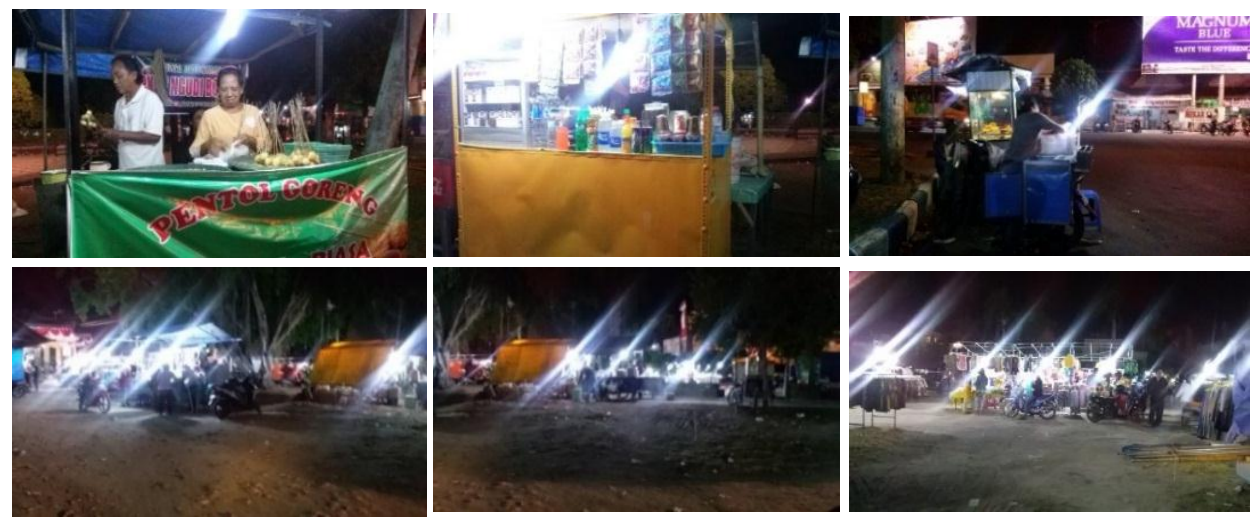

Gambar 3. Aktifitas PKL sehari-hari (sore-malam). 


\subsection{Dinamika ruang PKL saat lebaran}

Lebaran adalah momentum yang ditunggu juga oleh pedagang/PKL. Pedagang yang berjualan dialun-alun pada lebaran ini tidak hanya pedagang yang biasa berjualan di alun-alun sehari-hari melainkan juga pedagang dari luar kota, khususnya kelompok pasar malam yang berkeliling antar kota. Pedagang dari luar kota ini sudah paham betul bahwa pengunjung yang ke alun-alun pastilah banyak. Karena mereka sendiri juga sudah tahu adanya ungkapan "Durung riyayan yen durung ning aloon-aloon".

Pada saat lebaran inilah puncak/paling maksimal pedagang yang berjualan di alun-alun. Meskipun pada acara Grebeg Suro juga banyak pedagang, namun tidak sebanyak pedagang ketika lebaran. Pengunjung alun-alunpun paling banyak adalah ketika lebaran, hal ini didukung adanya para pemudik beserta rombongan keluarganya yang mengunjungi disamping pengnjung dari lokal dan luar kota.

Adanya ungkapan "Durung riyayan yen durung ning aloon-aloon" yang melekat dimasyarakat Ponorogo dapat dilihat pada alun-alun yang menjadi tempat termeriah dan ramai ketika waktu lebaran di Ponorogo. Masyarakat dari berbagai penjuru dengan latar belakang yang berbeda-beda mengunjungi dan beraktifitas alun-alun. Bermacammacam aktifitas kegiatan yang bisa dijumpai di alun-alun, ada yang berekreasi bersama keluarga, bernostalgia bagi pengunjung pemudik lebaran, berbelanja, jalan-jalan, nongkrong, berwahana permainan, berkeliling alun-alun, dan lain-lain. Aneka kegiatan aktifitas di alun-alun membentuk ruang sosial dan ekonomi.

Kearifan lokal yang ada adalah pedagang yang sudah berjualan sehari-hari di alun-alun tetap menempati tempat yang biasa dia berjualan. Sehingga bagi pedagang luar yang berjualan di alun-alun menempati tempat kosong lainnya. Semua terkoordinasi dengan baik sehingga potensi konflik perebutan konsumen bisa dihindari. Adapun tempat yang tidak boleh digunakan berjualan adalah panggung utama dan paseban. Paseban digunakan sebagai ruang pengamanan dan pusat informasi yang diisi dari pihak satpol PP, pemkab Ponorogo, kepolisian dan tenaga medis. Segala antisipasi kejadian yang mungkin terjadi harus dipersiapkan lebih awal. Banyak kemungkinan yang bisa terjadi mengingat jumlah pengunjung alun-alun pada pasar malam lebaran ini membludak, antara lain: anak hilang, ketegangan sosial, konflik antar pedagang, kebakaran, kecelakaan dan lain-lain.

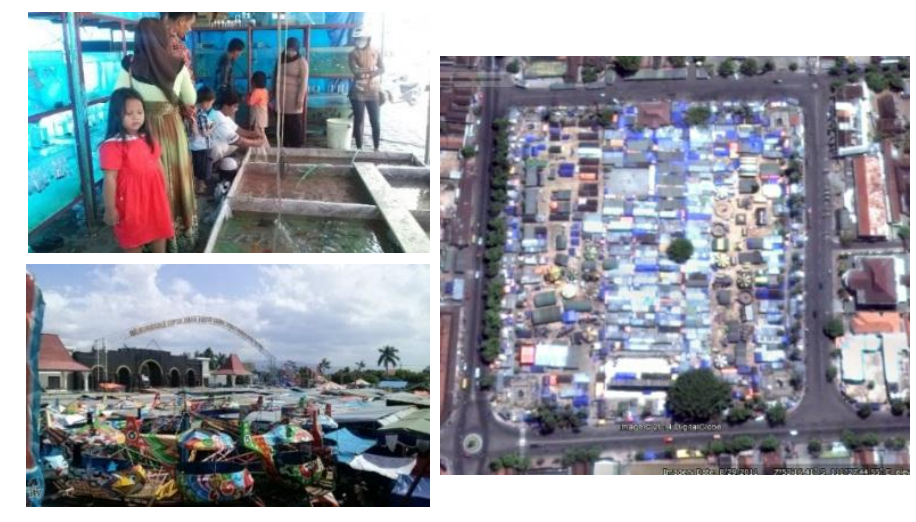

Gambar 4. Pasar malam lebaran alun-alun pada saat siang hari.

Pasar malam lebaran ini tidak hanya beroperasi pada malam hari saja melainkan mulai siang hari (gambar 4,5). Hal ini terjadi karena meskipun siang hari orang banyak yang berkunjung ke alun-alun, dimunkinkan karena hari-hari tersebut masih dalam libur cuti bersama lebaran idul fitri. Namun setelah libur cuti bersama lebaran idul fitri 
habis maka pasar malam hanya buka pada malam hari. Kemudian berangsur-angsur jumlah PKL berkurang sampai akhirnya kembali kekondisi sehari-hari dimana yang berjualan di alun-alun hanya PKL lokal.
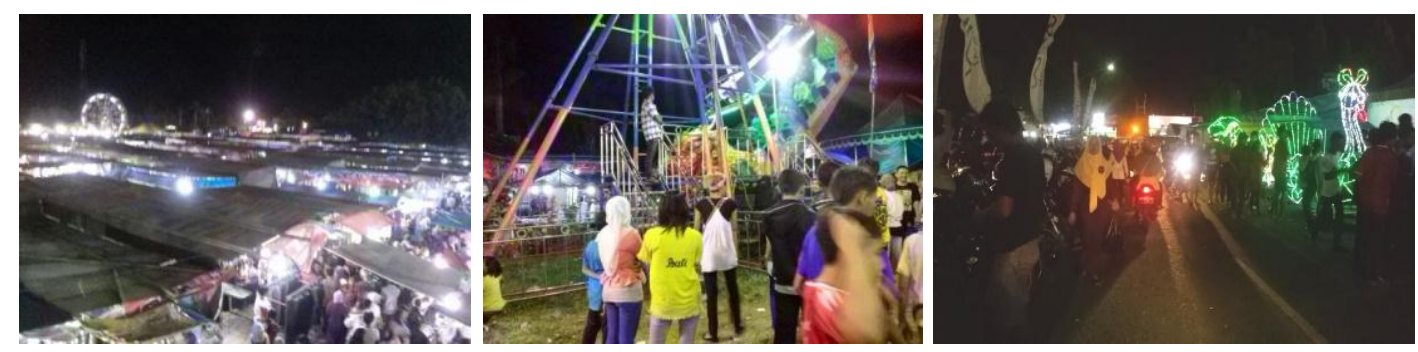

Gambar 5. Pasar malam lebaran alun-alun pada saat malam hari.

Dinamika ruang PKL yang terjadi adalah perubahan ruang PKL sehari-hari menjadi lebih luas dan banyak saat malam lebaran. Ruang-ruang PKL tersebut menjadi ruang ekonomi. Berbeda dengan kondisi pasar malam ketika masih bulan ramadhan (menjelang lebaran) yang ramai hanya pada malam hari, pasar malam lebaran ini mulai terjadi aktifitas sejak siang sampai dengan malam. Namun setelah kegiatan pasar malam lebaran selesai, ruang PKL yang yang ada kembali ke dinamika ruang PKL sehari-hari (gambar 6).

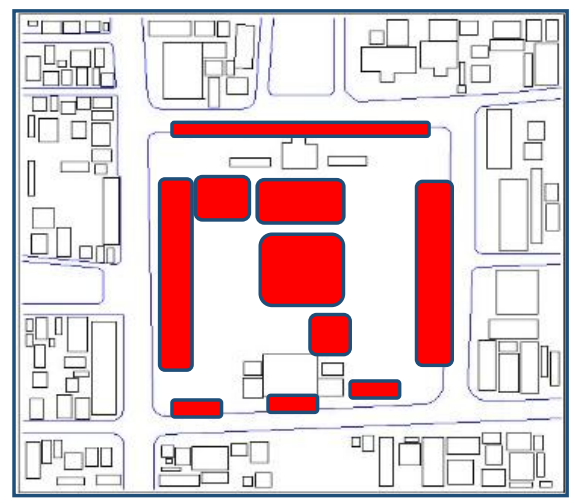

Gambar 6. Area penggunaan ruang alun-alun oleh PKL saat pasar malam lebaran.

Pada saat pasar malam lebaran/riyayan, area alun-alun yang telah terisi dengan bedak, lapak dan rombong PKL serta wahana permainan pada saat menjelang lebaran menjadi semakin padat karena masih ada beberapa PKL yang membuka usahanya setelah sholat Idul Fitri. Hampir tidak ada area di alun-alun yang tidak digunakan sebagai tempat beusaha. Berbeda dengan aktifitas pasar malam saat menjelang lebaran, aktiitas pasar malam terjadi sejak siang sampai malam hari karena pada waktu itu sudah tidak berpuasa. Sejak siang hari orang mulai beraktifitas, bagi PKL dan Penyedia Wahana mereka mulai membuka usahanya dan bagi pengunjung beraktifitas di alunalun sebagai aktifitas kegiatan berekreasi. Pengunjung beraktifitas sekedar jalan-jalan, melihat/membeli dagangan PKL, bermain di wahana atau membeli makanminum/barang untuk keperluannya.

\subsection{Dinamika ruang PKL saat grebeg suro}

Pasar malam adalah bagian dari acara Grebeg Suro. Pasar malam bertempat di alun-alun disekitar acara pertunjukkan Festival Reog Nasional. Keberadaan pedagang 
(PKL) di alun-alun adalah bukan hal yang baru. Namun lingkup skala dan pelaku PKL yang ada di pasar malam ini jauh lebih banyak dari jumlah PKL yang sehari-hari berjualan di alun-alun (gambar 7).

Pasar malam ini membentuk suatu ruang ekonomi. Aneka jenis usaha/komoditi perdagangan ditawarkan. Bisa dikata bahwa alun-alun saat pasar malam menjadi "mall tradisional one stop shopping". Pengunjung yang datang dari berbagai klasifikasi: dari yang tua sampai anak-anak, pria dan wanita, orang kaya sampai masyarakat ekonomi lemah, dari aneka profesi, pejabat dan rakyat, semua ada di alun-alun Ponorogo. PKL berjualan sampai meluber di jalan sekitar alun-alun, yaitu jalan Alun-alun Timur dan jalan Alun-alun Utara.
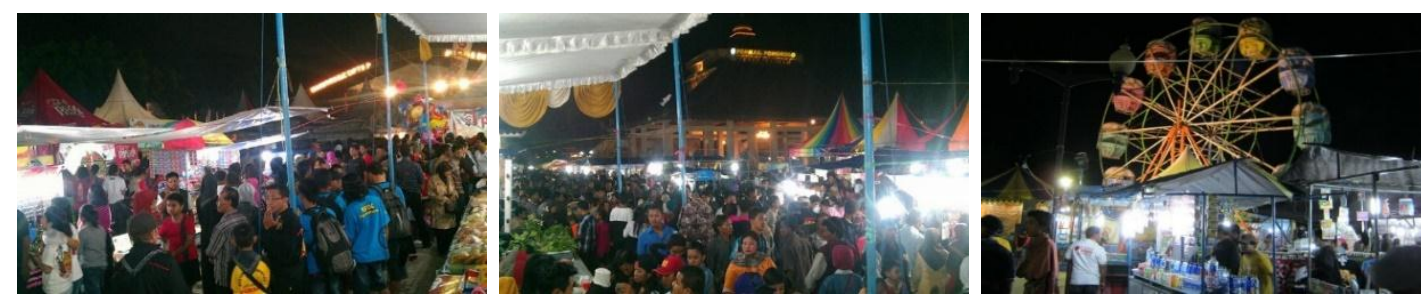

Gambar 7. Kegiatan pasar malam grebeg suro

Hal lain yang terjadi adalah banyaknya trotoar yang digunakan sebagai area berjualan PKL, menyebabkan pejalan kaki yang menuju alun-alun tidak bisa menggunakan trotoar dan jalan dibadan jalan. Tentu hal ini membahayakan bagi pejalan itu sendiri disamping membuat sirkulasi jalan semakin macet.

Pasar malam berlangsung berdampingan dengan penyelenggaraan Festival Reog Nasional. Namun kedua acara ini dapat berjalan beringan tanpa adanya konflik. Namun hierarki dalam penyelenggaraan acara di alun-alun adalah Festival Reog Nasional lebih utama. Hal ini dikarenakan acara Festival Reog Nasional adalah acara resmi dari pemerintah Ponorogo yang juga mengundang tamu-tamu resmi baik dari kabupaten tetangga, pemerintah provinsi, bahkan kalangan Nasional. Acara ini juga mengundang entitas-entitas yang masih memegang teguh tradisi, semisal : Raja-raja kesultanan Nusantara, Seniman dan Budayawan. Sehingga elemen PKL yang berada disekitar pagar pembatas area pertunjukkan Festival Reog Nasional adalah PKL yang tidak menimbulkan kebisingan/kegaduhan, semisal penjual makan-minum, baju/pernak pernik reog, bukannya PKL dvd atau wahana permainan.

Kearifan lokal lainnya adalah ketika waktu adzan, hinggar bingar musik atau kegiatan akan dimatikan atau sekurang-kurangnya dikecilkan volumenya, mengingat alun-alun berada dekat dengan Masjid Agung Kauman.

Peluberan PKL hanya diperbolehkan di alan alun-alun utara dan jalan alun-alun timur beserta trotoarnya. Hal ini dilakukan karena peluberan PKL tentu akan mengganggu sirkulasi jalan. Sedangkan jalan alun-alun selatan dan jalan alun-alun barat adalah jalan arteri penghubung antar kota yang diusahkan agar fungsi sirkulasi tidak terganggu.

Dinamika ruang PKL yang terjadi adalah perubahan ruang PKL sehari-hari menjadi lebih luas dan banyak saat malam grebeg suro serta perubahan jalan alun-alun utara dan jalan alun-alun timur semula yang hanya berfungsi sebagai jalan raya berubah menjadi ruang ekonomi bagi PKL pasar malam Grebeg Suro. Namun setelah kegiatan tersebut selesai, ruang yang yang ada menjadi ruang sirkulasi jalan kembali pada pagi dan siang hari karena PKL hanya buka pada malam hari (gambar 8). 


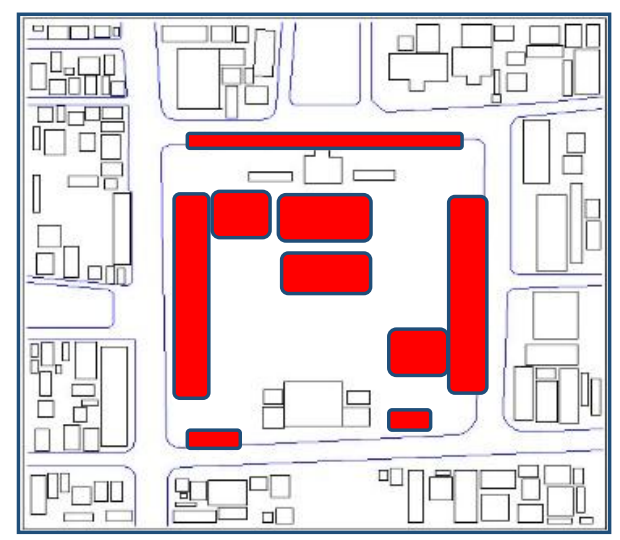

Gambar 8. Area penggunaan ruang alun-alun oleh PKL saat grebeg suro (malam hari).

\subsection{Kearifan lokal ruang PKL alun-alun Ponorogo}

Alun-alun di berbagai era dibuat dengan proses pendefinisian konsep dari penguasa untuk kepentingan legitimasi politik. Di era kerajaan Hindu pada abad VI M, misalnya, guna kepentingan legitmasi politik dan untuk meninggikan posisi raja maka alun-alun digambarkan sebagai tiruan kosmis. Di era masuknya agama Islam pada abad XIII M, guna melegitimasi politik syiar Islam secara damai maka alun-alun merupakan ruang untuk penyiaran agama melalui acara-acara yang dikemas dalam bentuk tontonan menarik. Bahkan di era kerajaan Mataram Islam pada abad XVI M, guna menyatukan peran dualisme raja maka alun-alun digambarkan sebagai tempat menyatunya kekuatan pemerintahan dengan agama. Di era kolonialisme Belanda pada abad XVI M, untuk kepentingan politiknya, kolonial Belanda menempatkan kawasan komersial guna mengalihkan perhatian masyarakat dari aura kewibawaan kabupaten. Dengan demikian dari evolusi alun-alun tersebut maka proses pendefinisian konsep alun-alun berada pada peran penguasa guna mengontrol kehidupan warga dan alat legitimasi guna meninggikan peran penguasa. Konstruksi alun-alun adalah konkretisasi dari ideologi penguasa [Rukayah,2007].

Saat ini banyak daerah yang berlomba-lomba menambah keindahan alun-alun menjadi taman kota namun mengusir dan meniadakan keberadaan PKL yang sebelumnya ada di alun-alun tersebut karena PKL dianggap menurunkan nilai estetika alun-alun. Namun pemerintah kabupaten Ponorogo mengambil kebijakan yang lain yang mungkin dianggap tidak populis. Penataan alun-alun harus tetap dilakukan dengan tetap mempertahankan eksistensi keberadaan PKL. Kekhawatiran asumsi pedagang kaki lima menghalangi penghargaan lingkungan PKL tidaklah dirisaukan oleh pemkab Ponorogo karena keyakinan bahwa dengan memberi kesempatan warganya (PKL) mencari nafkah di alun-alun akan dibalas dengan kesadaran dan komitmen yang tinggi PKL akan menjaga kebersihan dan ketertiban.

Diakui atau tidak keberadaan alun-alun sangat penting bagi setiap daerah. Lapangan besar itu bisa menjadi simbol tentang kondisi dan perkembangan suatu daerah. Hanya dengan melihat alun-alun, orang bisa menyimpulkan bagaimana kondisi daerah itu. Keberadaan alun-alun di pusat-pusat kota dan pusat pemerintahan dapat dijadikan tolok ukur perkembangan suatu daerah. Jika pemerintahan daerah itu seperti tubuh, maka alun-alun bisa diibaratkan sebagai wajahnya. Karena paling mudah dilihat, paling sering dipandang, maka wajar jika dijadikan tolok ukur untuk menilai seseorang meskipunpenilaian itu tidak selalu benar. 
Ponorogo sebagai daerah yang menata diri menuju kota wisata dan seni budaya, maka keberadaan alun-alun menjadi hal penting. Dalam penataan alun-alun Ponorogo secara bertahap, pemkab memiliki prinsip, yaitu mewujudkan alun-alun yang indah dipandang sekaligus ramah bagi pedagang. Diharapkan alun-alun menjadi tempat publik yang bersih, indah, nyaman, membanggakan, sekaligus bisa memberikan efek ekonomi masyarakat. Penataan alun-alun yang dilakukan secara bertahap disebabkan adanya keterbatasan anggaran yang dimiliki pemkab dan memberikan kesempatan agar tidak semua PKL terimbas kegiatan penataan. Sedikit banyak kegiatan penataan akan mengganggu, mengurangi dan membatasi aktifitas yang dapat dilakukan di alun-alun termasuk aktifitas PKL.

Bagi pemkab Ponorogo, pedagang merupakan salah satu ikon, aset dan juga objek yang memiliki nilai tinggi dari alun-alun. Keberadaan para pedagang itu tidak hanya menarik masyarakat datang ke alun-alun dan memberikan warna tersendiri, tetapi juga sebagai komitmen pemkab Ponorogo dalam pemberdayaan ekonomi masyarakat. Setiap hari, mulai siang hingga malam diberikan ruang bagi PKL yang mayoritas warga Ponorogo untuk berjualan. Bahkan saat lebaran, saat tahun baru atau perayaan Grebeg Suro, PKL diberikan ruang khusus sehingga bisa menggunakan area lebih di alun-alun untuk aktifitas berdagang di luar area yang ditetapkan untuk PKL sehari-hari.

Aktifitas ekonomi di alun-alun ternyata sangat tinggi. Pada hari normal saja, perputaran dipekirakan mencapai puluhan juta setiap hari. Apalagi saat pasar malam lebaran atau event khusus perputaran uang diperkirakan mencapai Rp 5 miliar. Belum termasuk uang parkir, uang yang berputar disekitaran alun-alun dan kawasan kota. Sehingga keberadaan pedagang selain memberikan kontribusi kepada pemkab melalui retribusi dan pendapat asli daerah lainnya, juga menjadi ladang pencarian rezeki ratusan pedagang itu sendiri.

Keberadaan PKL juga dinaungi oleh Peraturan Daerah Kabupaten Ponorogo nomor 1 tahun 2012 tentang Rencana Tata Ruang Wilayah Kabupaten Ponorogo tahun 2012 - 2032. Dalam RTRW Ponorogo mengatur kawasan peruntukan bagi sektor informal perkotaan antara lain:

1. Kawasan taman kota di Kelurahan Nologaten Kecamatan Ponorogo; dan

2. Kawasan sekitar aloon-aloon Kelurahan Mangkujayan Kecamatan Ponorogo.

Atas kebijakan inilah maka area alun-alun juga dikembangkan sebagai area pengembangan PKL terkontrol. Area lapangan perkerasan dan sekitar trotoar alun-alun diperbolehkan untuk kegiatan usaha PKL. Namun keberadaan PKL ini harus tetap terikat dengan ketentuan yang ada. Dalam rangka memudahkan pengorganisasian, maka PKL-PKL tersebut dikelompokkan dalam suatu wadah/paguyuban.

Kesadaran PKL atas alun-alun sebagai aset pemerintah dan berhak penuh atas pengaturan di alun-alun menyebabkan PKL tidak merasa memiliki hak penuh atas alunalun. Kesadaran aktifitas usaha PKL mereka karena mendapatkan ijin dari pemkab Ponorogo. Ketika PKL diminta untuk tidak beraktifitas sementara dengan alasan yang bisa diterima PKL maka akan ditaati. Komunikasi yang baik dan harmonis antara PKL dan Pemkab Ponorogo menjadikan minim konflik antara keduanya. Dalam rangka meminimkan konflik dan memudahkan pengorganisasian PKL, maka dibentuklah Paguyuban PKL Alun-alun Ponorogo. Paguyuban ini menjadi ajang mempererat persaudaraan, wadah menyampaikan aspirasi, wadah menyelesaikan konflik antar PKL dan wadah sosialisasi. 


\section{Kesimpulan}

Keberadaan PKL dengan aktifitasnya di alun-alun Ponorogo membentuk suatu dinamika ruang tersendiri. Para PKL yang berinteraksi dengan pengunjung alun-alun dengan seting dan atributnya pada suatu waktu tertentu membentuk ruang -ruang ekonomi yang berubah-ubah sehingga membentuk dinamika ruang PKL tersendiri. Keberadaan PKL yang mempunyai manfaat melalui aktifitasnya dan mengandung nilainilai positif justru difasilitasi keberadaannya oleh pemerintah untuk beraktifitas di alunalun Ponorogo. Kelembagaan dan nilai-nilai positif yang dianut dari semua stakeholders alun-alun Ponorogo khususnya PKL menjadi sebuah kearifan lokal yang menjadi ciri/kekhususan tersendiri alun-alun Ponorogo.

Akan tetapi perkembangan PKL di alun-alun harus tetap diawasi dan dikontrol. Karena bilamana tidaak dilakukan hal tersebut dapat menyebabkan konflik penggunaan ruang.

\section{Daftar Pustaka}

Handinoto. 1992. Alun-alun Sebagai Identitas Kota Jawa, Dulu dan Sekarang. Jurnal Dimensi. 18.

Rukayah, S, Soetomo, S. 2007. Refrensi Soekarno Dalam Memaknai Sejarah dan Konsep Alun-alun di Indonesia. Journal of Historical Studies. 3(2).

Santoso, EB. 2008. Studi Perencanaan Penataan Kawasan Alun-alun Kota Brebes. Jurnal Teknik Sipil \& Perencanaan. 10(2).

Suwardjoko. 2009. Alun-alun. Bulletin Penataan Ruang. Jakarta. Kementerian PU.

Wiryomartono, BP. 1995, Seni Bangunan dan Seni Bina Kota di Indonesia: Kajian Mengenai Konsep, Struktur, dan Elemen Fisik Kota Sejak Peradaban Hindhu-Budha, Islam Hingga Sekarang, Jakarta. Gramedia Pustaka Utama. 